\title{
NALLD JOURNAL
}

\author{
ISSUE HIGHLIGHTS:
}

\section{THE USES OF TWO-WAY \& SATELLITE}

\author{
TELEVISION TO TEACH
}

FOREIGN LANGUAGES

Dale V. Lally Jr., Issue Editor

Journal of the International Association for Learning Laboratories Volume 18, Number 1

Fall 1983 


$\begin{array}{ll}\text { Editor-in-Chief } & \text { Dale V. Lally Jr, University of Louisville } \\ \text { Co-Editor } & \text { Denzil Edge, University of Louisville } \\ \text { Co-Editor } & \text { Robert N. St. Clair, University of Louisville } \\ \text { Regional Editors } & \text { Charles P. Richardson, Ohio University } \\ & \begin{array}{l}\text { Flint Smith, Purdue University } \\ \text { Advertising Manager Iris Wingert, University of Maryland-Baltimore } \\ \text { County }\end{array}\end{array}$

\section{DEPARTMENTS}

\section{Conference Updates Dale V. Lally Jr, University of Louisville NALLD News Editors}

NALLD JOURNAL

The NALLD JOURNAL (New Advances in Learning Laboratory Developments ISSN 0027-5905) is currently published three times annually (Fall, Winter, Spring/Summer) by the International Association of Learning Laboratories (IALL). Membership in the Association is open to anyone associated with or interested in furthering the effective use of media in all areas of instruction. Membership year begins on October 1 and includes a subscription to the JOURNAL.

Opinions expressed in signed articles are those of the authors. Although the JOURNAL editors attempt to screen advertising for integrity, all advertising remains the responsibility of the advertiser. Neither opinions expressed in the articles nor advertising carry IALL approval unless specifically adopted by the IALL Executive Board. The NALLD JOURNAL is indexed in the CURRENT INDEX OF JOURNALS IN EDUCATION and is cited LANGUAGE AND LANGUAGE BEHAVIORAL ABSTRACTS.

RATES (Beginning with Volume 17): North America 515; all other areas and institutions \$20; students \$10. Sustaining memberships \$100. Back Issues are $\$ 7$ each. This publication is available on microfilm from: University Microfilms International, 300 North Zeeb Road, Dept. P.R., Ann Arbor, MI 48106 or 30-32 Mortimer St., Dept. P.R., London WIN 7RA England.

Manuscripts submitted for review should be double-spaced and sent in triplicate to NALLD JOURNAL, A\&S Learning Lab, Bingham Humanities 16, University of Louisville, KY 40292. Submissions should follow the guidelines of the PUBLICATIONS MANUAL of the American Psychological Association (1974, rev) and/or A MANUAL OF STYLE, University of Chicago Press (12th ed.) The editors will also accept the MLA format.

Dues, subscriptions, changes of address, and orders for back issues should be sent to the JOURNAL at the address indicated above. Payment is required in U.S. funds drawn on U.S. or Canadian banks. Make all checks payable to IALL.

Advertising queries should be sent to Iris Wingert, NALLD Advertising Manager, Instructional Media Resources, University of Maryland-Baltimore County, Catonsville, MD 21228.

POSTMASTER: Send Form 3579 to NALLD JOURNAL, Bingham Humanities 16, University of Louisville, KY 40292 . Third class postage paid at Louisville, Kentucky. Copyright 1983 by the International Association of Learning Laboratories. 
NALLD JOURNAL:

New Advances in

Learning Lab

Developments.

\section{President \\ Victor Aulestia \\ University of \\ Maryland-Baltimore \\ County}

Vice President

Roger Sanchez

Wesleyan University

Executive Sec'y

Charles P. Richardson

Ohio University

\section{Treasurer \\ Leslie Bailey \\ Northwestem \\ University}

\section{Recording Sec'y \\ Mary Lynne \\ Flowers \\ University of \\ Kentucky}

\section{Joumal Editor}

Dale V. Lally, Jr.

University of

Louisville

\section{TABLE OF CONTENTS}

Two Way Instructional Television-A Technological Alternative for the 1980 's . . . . . . . . . 5

Anne Volkman

The Impact on a Foreign Language Curriculum of Foreign Language Television Signals Received from Ceosynchronous Earth Satellites . . . . 21

Victor H. Aulestia

ASSOCIATION NEWS-IALL Program at the AECT Convention.... Robin Lawrason . . . . . . 25

CALL FOR PAPERS ....Editor . . . . . . . . . 27

\section{REVIEWS}

Film/Videotape...Spanish film NIEBLA by Migual de Unamuno ................ 29

Book....Curriculum, Competence, and the Foreign Language Teacher from ACTFL. . . . . 33

Computer software...Schoolhouse SoftwareBasic \& Intermediate French series . . . . . . . 35

NEWS ABOUT...books, materials, summer study opportunities . . . . . . . . . . . . 43

EDITOR'S CORNER

CONFERENCE CALENDAR....Editor . . . . . . .49

INTERNATIONAL EDITORIAL CONSULTANTS

Liliana Baltra

Takashi Kuroda

Centro de Perfecctonamiento, Language Laboratory Asso-

Experimentacion e investiciation of Japan

gaclones Pedagogicas (CPEIP) English Literature Department

Casilla 16162

Santiago 9, Chtle

Otsuma Womens College 12, 3- Bancho, Chiyoda-ku Tokyo, 102, Japan

Yakov Borisovich Krupatkin

u.l. Odesskaja 1, kv. 19

Sebastopol 335000, USSR
Reinhold Freudenstein Foreign Language Research Information Center

Lahnberge

D-3550 Marburg/Lahn

Federal Republic of Germany 


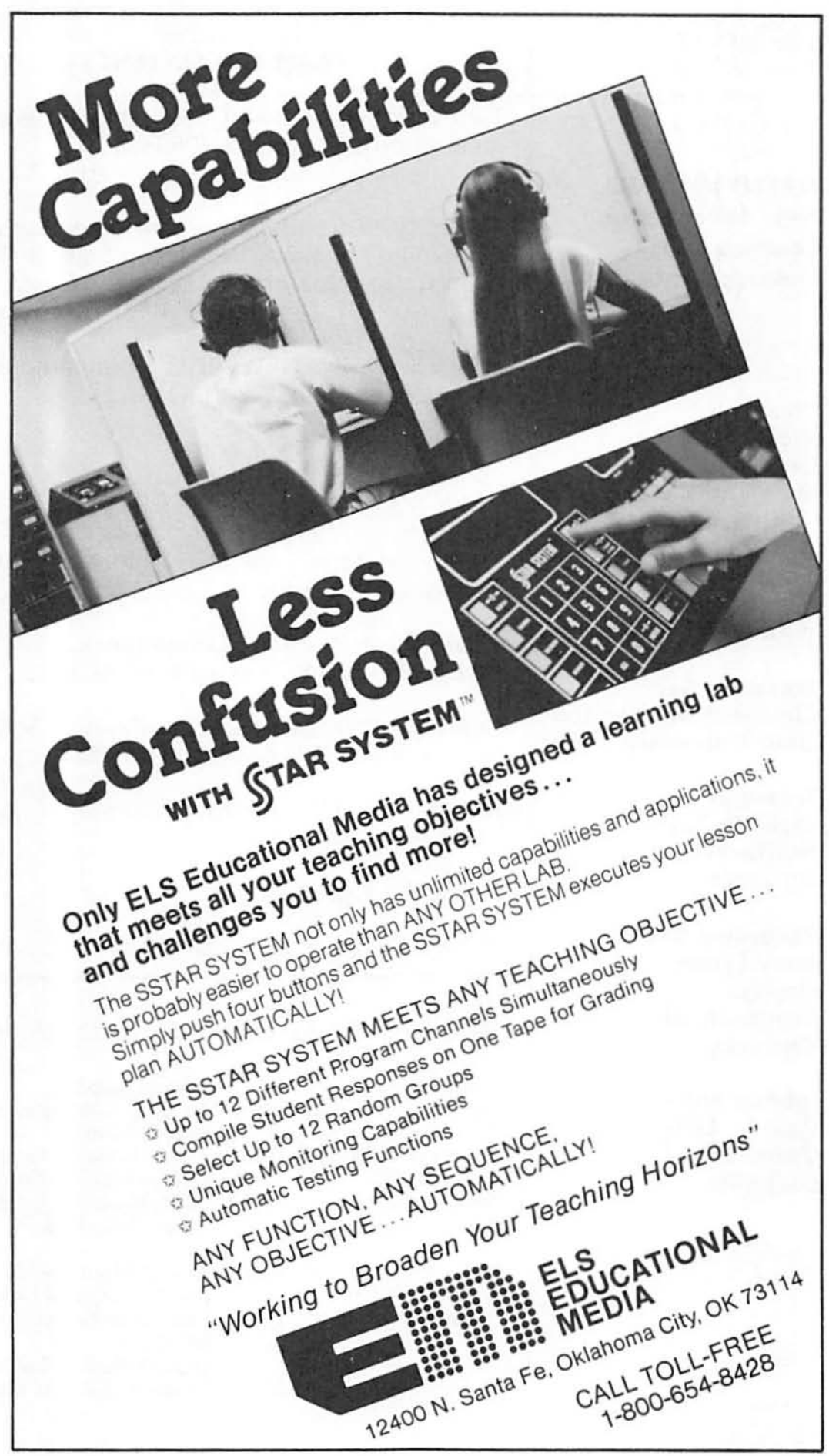

